\title{
The Development of Activity Literacy Teaching Material Based on Multimodal of Literacy for the grade 4th at SDS Amir Hamzah
}

\author{
Isma Damayanti ${ }^{1}$, Mutsyuhito Solin ${ }^{2}$, Evi Eviyanti ${ }^{3}$ \\ ${ }^{1}$ Postgraduate Program in Universitas Negeri Medan, Indonesia \\ ${ }^{2,3}$ Universitas Negeri Medan, Indonesia \\ damayantiisma.id@gmail.com
}

\begin{abstract}
This study aims to: (1) Describe the development of multimodal literacy-based literacy teaching materials at SDS Amir Hamzah. (2) Testing the feasibility of teaching materials for literacy activities based on multimodal literacy at SDS Amir Hamzah. (3) Testing the effectiveness of teaching materials for literacy activities based on multimodal literacy at SDS Amir Hamzah. This research is a development research using the ADDIE development model, namely: Analysis, Design, Development, Implementation, and Evaluation. The subjects of this study were the fourth grade students of SDS Amir Hamzah in the 2019/2020 academic year consisted of 21 students. The instruments used are questionnaires of expert validity, student and teacher responses, and student performance rubrics using literacy activity teaching materials. The results of this study indicate that (1) the process of developing teaching materials for literacy activities based on multimodal literacy includes five steps, namely: analysis, design, development, implementation, and evaluation. (2) The literacy activity teaching materials of multimodal literacy-based are feasible to use with an average percentage of $88.47 \%$ and very feasible criteria. (3) The effective multimodal literacy-based literacy activity teaching materials are used with a gaincore value of 0.575 .
\end{abstract}

Keywords

teaching material;

activity literacy;

multimodal literacy

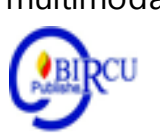

\section{Introduction}

Literacy was initially defined as 'literacy' and later interpreted as 'literacy' or 'understanding'. Then, "literacy in reading and writing" is emphasized because these two language skills are the basis for the development of understanding in various things (Laksono, et al., 2018: 1). In the end, the basic meaning of literacy as literacy skills becomes a way for the development of literacy meaning more broadly. In addition, literacy is also closely related to literacy. This is in line with what was stated by Benjamin and Hugelmayer (2013), namely "Literacy is defined as the ability to read and write. The more we develop our students' listening and speaking skills, the stronger their reading and writing skills will be. 'Literacy is defined as reading and writing skills. The more listening and speaking skills students develop, the stronger their reading and writing skills are.

Literacy development efforts should not stop when students can read and write fluently, but students must have good reading interests. Good reading skills and interest eventually lead to increased literacy so that individuals can optimize access to information and knowledge through reading activities and applying it in their daily activities. Therefore, 
students really need literacy in order to be able to adapt to this 21 st century. This is supported by data obtained by the World Economic Forum (2016) that students need 16 skills to be able to survive in the XXI century, namely those which are collected in basic literacy (how students apply literacy skills for everyday life), competence (how students respond to challenges complex), and character (how students respond to changes in their environment).

However, in reality, Indonesia's performance in international literacy assessments is still not very good. Indonesia's score on the PISA (Program for International Student Assessment) or the International Student Assessment Program organized by the OECD (Organization for Economic Co-operation and Development) to measure the cognitive skills of 15 year old students in three aspects of literacy, namely language literacy (reading), mathematical literacy, and scientific literacy in various countries.

PISA results in 2018 show that Indonesia is quite far apart from other countries. The skills of the three aspects of literacy are at the international average, namely Reading competence of 487, Mathematics and Science competence of 489. Meanwhile, Indonesia's score did not even make it through the score above 400 for the three of them, respectively, the scores for Reading, Mathematics, and Science from the test results in 2018 were 371, 379, and 396.These scores decreased compared to the PISA test in 2015, namely the Indonesian Reading, Mathematics and Science competencies respectively achieved a score of 397, 386, 403. Based on the PISA results from 2012 to 2018, Reading competency scores had the lowest score decline (www.zenius.net).

Based on the results of an interview with one of the teachers at SDS Amir Hamzah, currently the school literacy movement program at SDS Amir Hamzah has not optimally developed the literacy skills of its school residents, especially teachers and students. This is due to the lack of understanding and awareness of school members about the importance of literacy skills in an effort to develop the potential of each individual, the availability and use of teaching materials in elementary schools that support literacy activities are still lacking so that there is less variety of literacy activities carried out by students. Literacy activities in schools currently do not accommodate the activities of managing information from various multimodals. Literacy activities are still at the habituation stage, namely reading 15 minutes before the development and learning stages.

15 minutes of reading activity is not enough to improve students' literacy skills. There are still teachers as literacy practitioners who have not optimally developed a variety of literacy activities according to the needs and development of students. This means that the teacher still carries out the 15-minute reading activity which is uniform across all levels, ages and characteristics of the child. The uniformity of reading duration for 15 minutes also creates new problems, namely students with all their uniqueness, diverse potential and abilities then receive the same literacy activity treatment, of course it is not effective. The reading duration of 15 minutes is not sufficient for the teacher to guide students in active reading, provoke curiosity, find the meaning of the reading and discuss the results of the reading.

Literacy is not just reading but the ability to access, evaluate, and integrate information from a wide range of textual sources (Reardon, et al., 2012: 17). Accessing and managing this information in various multimodal sources in the form of oral, audio, visual, spatial, gestural and / or audio-visual sources in its application to teaching materials that support literacy activities in the form of photography, illustration, typography, symbols and / or a combination of all of them to obtain meaningful learning. Dewi (2019: 2) who stated that, in this era of revolution 4.0, literacy competence is very important. Literacy began to be defined 
as the ability to understand various texts in various forms beyond reading and writing, including the types of text in the form of images, graphics, electronics, including kinesthetic.

The main teaching materials currently used in the implementation of the 2013 curriculum are oriented to the integrated thematic book of the 2013 curriculum published by the Ministry of Education and Culture of the Republic of Indonesia in 2017. However, these books have not been able to increase literacy activities optimally. The teaching materials in elementary schools are still lacking in literacy activities and have not involved students in finding the meaning of reading from various forms of text or multimodal literacy. Whereas according to Prastowo (2015: 5) in core competencies which include pedagogic competence, personality competence, social competence and professional competence, teachers and lecturers are required to be able to compile innovative teaching materials which can be in the form of printed teaching materials, models / mockups, audio teaching materials, Audiovisual teaching materials or interactive teaching materials in accordance with the curriculum for developing student needs and developments in information technology.

Based on the analysis of several teaching materials, activities on the market today still have shortcomings such as not involving various multimodals, not integrating literacy in learning, not optimally involving students in various literacy activities that are varied, challenging and meaningful. Therefore, literacy activity teaching materials are needed which include various multimodal-based activities for learning in the 21 st century.

The purpose of this development is to: In relation to the research problems described in the problem statement, the objectives of this research are: (1) Describe the process of developing activity literacy teaching material based on multimodal of literacy for the grade $4^{\text {th }}$ at SDS Amir Hamzah. (2) Describe the feasibility of activity literacy teaching material based on multimodal of literacy for the grade $4^{\text {th }}$ at SDS Amir Hamzah. (3) Describe the effectiveness of activity literacy teaching material based on multimodal of literacy for the grade $4^{\text {th }}$ at SDS Amir Hamzah.

\section{Review of Literatures}

\subsection{Activity Literacy Teaching Material}

Abidin (2014: 263) defines teaching materials as a set of facts, concepts, principles, procedures, and / or generalizations designed specifically to facilitate teaching. Teaching materials are all materials (both of information, tools, and text) that are arranged systematically to show a complete figure of competencies that will be mastered by students and used in the learning process (Praswoto, 2015: 17). Teaching materials are all forms of material, both written and unwritten, which are used to assist teachers / instructors in carrying out teaching and learning activities. Teaching materials can be in the form of printed teaching materials, audio teaching materials, audio-visual teaching materials and interactive teaching materials (Majid, 2013: 173).

Based on the description above, it can be concluded that teaching materials are a set of learning materials (information, tools, and texts) that are collected and presented systematically and dynamically containing knowledge, skills, and attitudes that students must learn to achieve learning goals. In this study, the teaching materials developed are literacy activities teaching materials where the teaching materials are arranged with a variety of activities that improve the literacy skills of students and teachers. This literacy activity teaching material is related to literacy practices related to making the best use of class time by integrating literacy in every learning activity. These activities, for example, begin with reading or watching videos and other types of materials that can be used in literacy learning, 
then gallery activities of students' simple works involving media literacy, culture, and other literacies as the development of student life skills.

\subsection{Multimodal of Literacy}

At present, written texts are often no longer a mode of representation in learning materials - textbooks, teacher materials, while pictures are increasingly prominent as carriers of meaning (Bezemer and Kress, 2008: 166). At that time, writing and images had become the main means of representing content (Kress and Leeuwen, 2006: 17). This is because technology is the only one that has an impact on the way of communication and human social change. People now can communicate instantaneously with a combination of text, photos, or videos through cell phone technology, various types of computers and multimedia devices (Kress and Leeuwen, 2001: 2).

Agreeing with Kress and Leeuwen, Abidin (2015: 56) also argues that in its development, literacy used in various fields of science uses media as a means of communication and meaning formation, efforts to understand information critically are not only done by using media in the form of language in a narrow view, meaning can be better understood through the use of various communication media such as pictures, videos, films, and various other literacy media or so-called multimodal.

Writing and drawing relationships are often recognized as part of multimodality. Multimodal text refers to meaningful written text that is combined with other modes such as images, sound, movement and movement (Walsh, 2011: 12). The dominance of multimodality has started to increase. Not only magazine pages or art media but also in the teaching and learning system. Multimodal learning is believed to encourage teachers to think about how to involve students in seeing various forms of text (Thompson, 2008: 144).

According to Sari, et al. (2013: 247), the multimodal concept in education which refers to the many types of materials that can be used in literacy learning has implications for the emergence of the concept of multiliteracy. This concept is a form of awareness of the various ways humans communicate and carry out reading and writing activities as well as types of materials or media for reading and writing activities. This implies the extent of the critical analysis that must be done to interpret the text.

Based on the description above, it can be concluded that the multimodal approach to literacy is the concept of literacy and various forms of representation and communication referring to the many types of materials that can be used in literacy learning to help students negotiate broader types of text and ways of persuasion such as oral, audio sources, visual, spatial, gestural and / or audio-visual so that students will get a lot of inspiration, have rich ideas and insights. In the end, learning becomes meaningful.

\subsection{Literacy}

Literacy is defined as 'the ability to read and write' which then develops into 'the ability to master certain field knowledge' (Wierdarti, et al., 2018: 7). Literacy is now not only defined as the ability to read and write, but according to Kucer (2014: 329) that: literacy was examined through a number of different lenses. The linguistic and other sign systems (text focus), cognitive (mind focus), sociocultural (group focus), and developmental (growth focus) dimensions of literacy dimensions of literacy and their interrelationships were addressed. Kern (2000: 67) defines the term literacy comprehensively that Literacy is the use of socially, and historically, and culturally situated practices of creating and interpreting meaning through texts. It entails at least a tacit awareness of the relationships between textual conventions and their context of use and, ideally, the ability to reflect critically on those relationships. Because it is purpose sensitive, literacy is dynamic not static and variable 
across and within discrouse communities and cultures. It draws on a wide range of cognitive abilities, on knowledge of written and spoken language, on knowledge of genres and on cultural knowledge.

Based on the above statement, it can be seen that literacy requires complex abilities. In the realm of learning, literacy skills are an important ability that every student must have. Literacy skills are needed by students in an effort to master various subjects including mastery of the domains of knowledge, skills, and attitudes. Therefore, literacy skills are not limited to cognitive abilities, but more complex abilities include linguistic aspects and other sign systems, social and cultural aspects, psychological aspects, and other aspects.

In the current era of revolution 4.0, all lines of society, both students, parents, teachers are required to always develop and perfect their abilities properly and massively in using and creating various types of texts through the use of technology and context with the hope that everyone can apply them as a means of lifelong learning. The literacy ability of each individual is increasing, so will the quality of life of a literate, high civilized and advanced society increase.

\section{Research Methods}

This research was conducted online in May to June at SDS Amir Hamzah in grade 4th 2019/2020 academic year. This research used research and development ( $R$ \& D). This research refers to the ADDIE development model. This model consists of five stages, namely Analize, Design, Development, Implementation, and Evaluation (Sani et al, 2018: 241). The research model and development of research models were used to produce certain products and test the effectiveness of these products.

The data obtained is the data validation of teaching materials for literacy activities based on multimodal literacy. This data was collected through material expert validation, linguist validation, expert validation of book layout design and questionnaires given to teachers and 4th grade students of SDS Amir Hamzah. The assessment questionnaire was given to validators, teachers and students which were presented in the form of a Likers Scale which had been given a score of $4,3,2,1$. Then the data were analyzed descriptively quantitatively, namely calculating the percentage indicator for each teaching material developed.

Based on Circular No. 4 of 2020, the Minister of Education and Culture of the Republic of Indonesia regarding the Implementation of Education Policies in an Emergency the Spread of Coronavirus Disease (Covid-19) states that regarding the increasing spread of Coronavirus Disease (Covid-19), the physical and mental health of students, teachers school principals, and all school members are the main considerations in the implementation of education policies. Therefore, the learning process is carried out from home through online / distance learning to provide a meaningful learning experience for students, so this research was conducted online using the Whatsapp Group application managed by the classroom teacher.

\section{Discussion}

The process of developing activity literacy teaching material based on multimodal of literacy is carried out in several stages, namely Analysis, Design, Development, Implementation, and Evaluation. At the analysis stage, based on the analysis of teacher needs, the results show that the School Literacy Movement (GLS) activities have not been optimally implemented in schools because literacy activities are still at the habituation stage, namely 
reading 15 minutes at the beginning of learning. Teachers have used everything in the school environment as a means of learning, such as books, magazines, and videos. However, teachers have not been able to use multimodal literacy in the form of oral / spoken, audio, visual, spatial, gestural and / or audio-visual sources. In fact, students are very enthusiastic when carrying out literacy activities at school by reading books, reviewing reading content, storytelling pictures, videos, films, the internet or other sources. Therefore, teachers need literacy activity teaching materials as a guidebook to help carry out the School Literacy Movement (GLS) activities using multimodal literacy so that teachers and students have references and directions when carrying out literacy activities every day so that these activities become meaningful, fun for teachers, and students.

In addition, the six basic literacy demands (literacy, literacy, numeracy, scientific literacy, digital literacy, financial literacy, cultural literacy and citizenship) must be mastered by students and must be learned in the context of the 2017 version of the 2013 curriculum. Therefore, the researchers developed teaching materials by determining core competencies and basic competencies according to the 2013 curriculum which contains these six basic literacies. The basic competencies that students need to learn are competencies related to fictional text material, style and movement, economic activities and their relationships, the benefits of the diversity of individual characteristics, and regional creation dance movements.

At this design stage, the researcher designs the product based on the results of the previous analysis. The results of the design stage that have been carried out by researchers are as follows:

\section{a. Preparation of the Teaching Materials Framework}

The initial product of the instructional materials developed is teaching materials in the form of literacy activity book.

\section{b. Systematics Determination of Teaching Materials}

Systematics or the order in which the material is presented is based on the elaboration of the core competencies and basic competencies that have been determined to be indicators in literacy activities.

\section{c. Preparation of Assessment Instrument Design}

The literacy activity book assessment instrument is in the form of a product feasibility questionnaire, student performance rubrics using literacy activity teaching materials, student and teacher responses questionnaires. This product feasibility questionnaire produces data sourced from learning material experts, design experts, linguists, teachers and students.

Furthermore, researcher develops the teaching materials with the following steps:

\section{Pre Writing}

The development of this teaching material begins with determining basic competencies and learning objectives, then collecting the various of information related to material, illustrations, pictures, multimodal and other materials from various sources such as text books, articles, relevant reading books, the internet and other sources.

\section{Compiling Teaching Materials}

The preparation of teaching materials is carried out by compiling each section based on the BSNP indicators. 

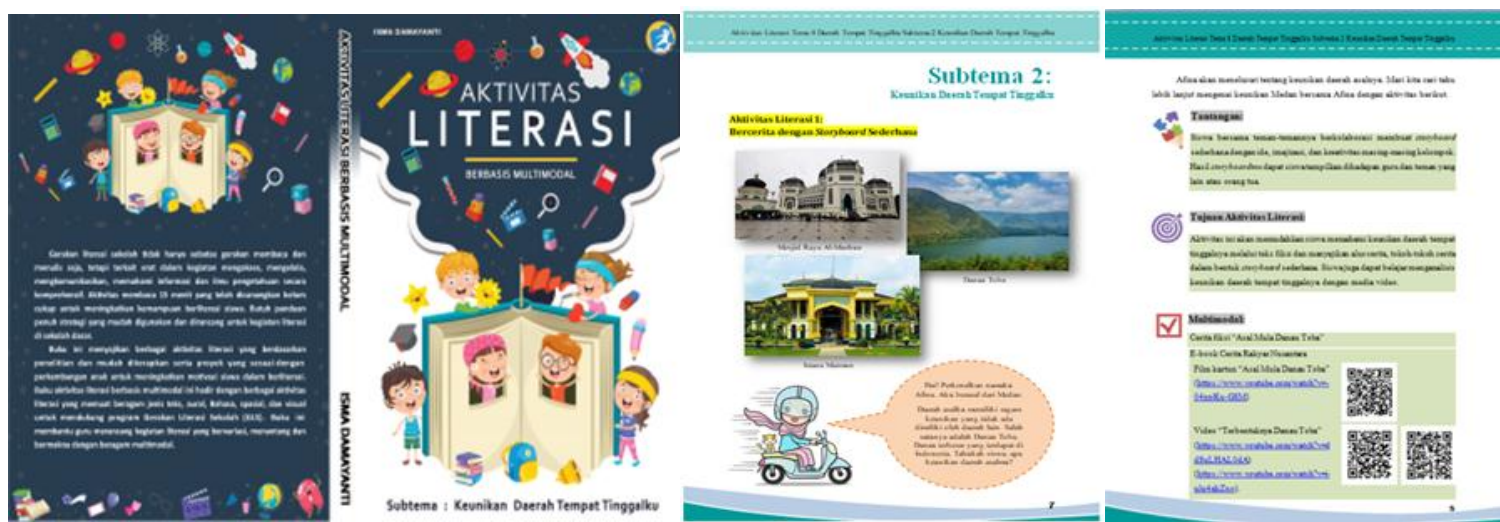

Figure 1. Cover Literacy Activity Book

Figure 2. The Content Of Literacy Activity Book

3. Feasibility of literacy activity teaching materials

The results of the feasibility of teaching materials for literacy activities based on data from the validation process by expert validators and the average value of the proportion of teacher and student response questionnaires. The following are the results of material experts, design experts, and linguist.

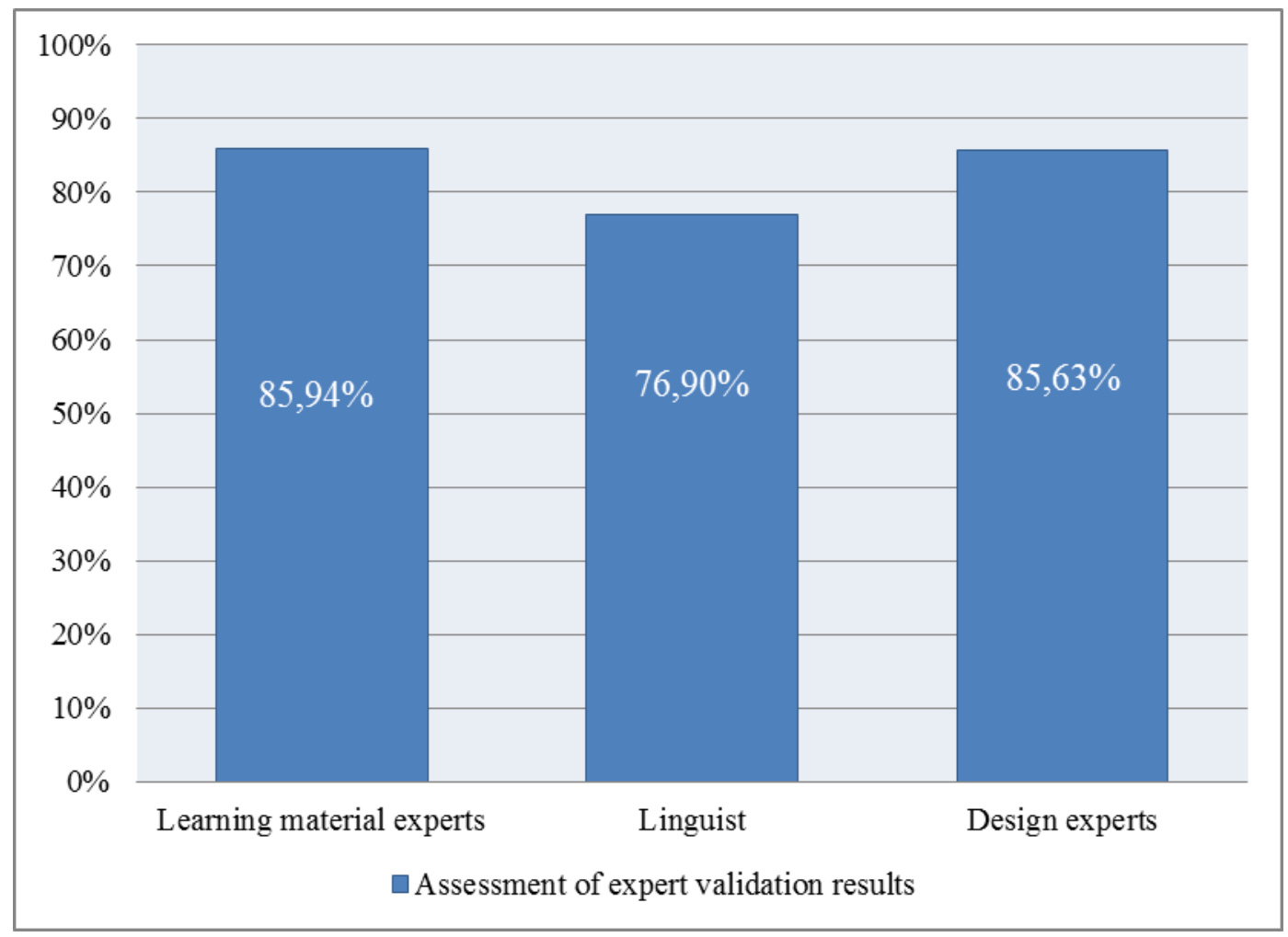

Diagram 1. Assessment of Validation Results

The diagram above shows that the assessment of the results of expert validation (material, design, and linguist) on multimodal-based literacy activity teaching materials has the criteria that it is feasible to be tested in the field with a difference in the percentage that is not too significant. The highest assessment was found in material experts with an average percentage of $85.94 \%$ and categorized as very feasible. Then, assessment of design expert with an average percentage of $85.63 \%$ and categorized as very feasible. While the lowest assessment of linguists with an average percentage of $76.9 \%$ and categorized as feasible, and 
the average percentage score of the three expert validations reached a score of $83 \%$ which was very feasible.

Teacher response questionnaires are given to determine the responses of teachers and students to the teaching materials that have been developed. The results of data analysis can be seen in the diagram as follows:

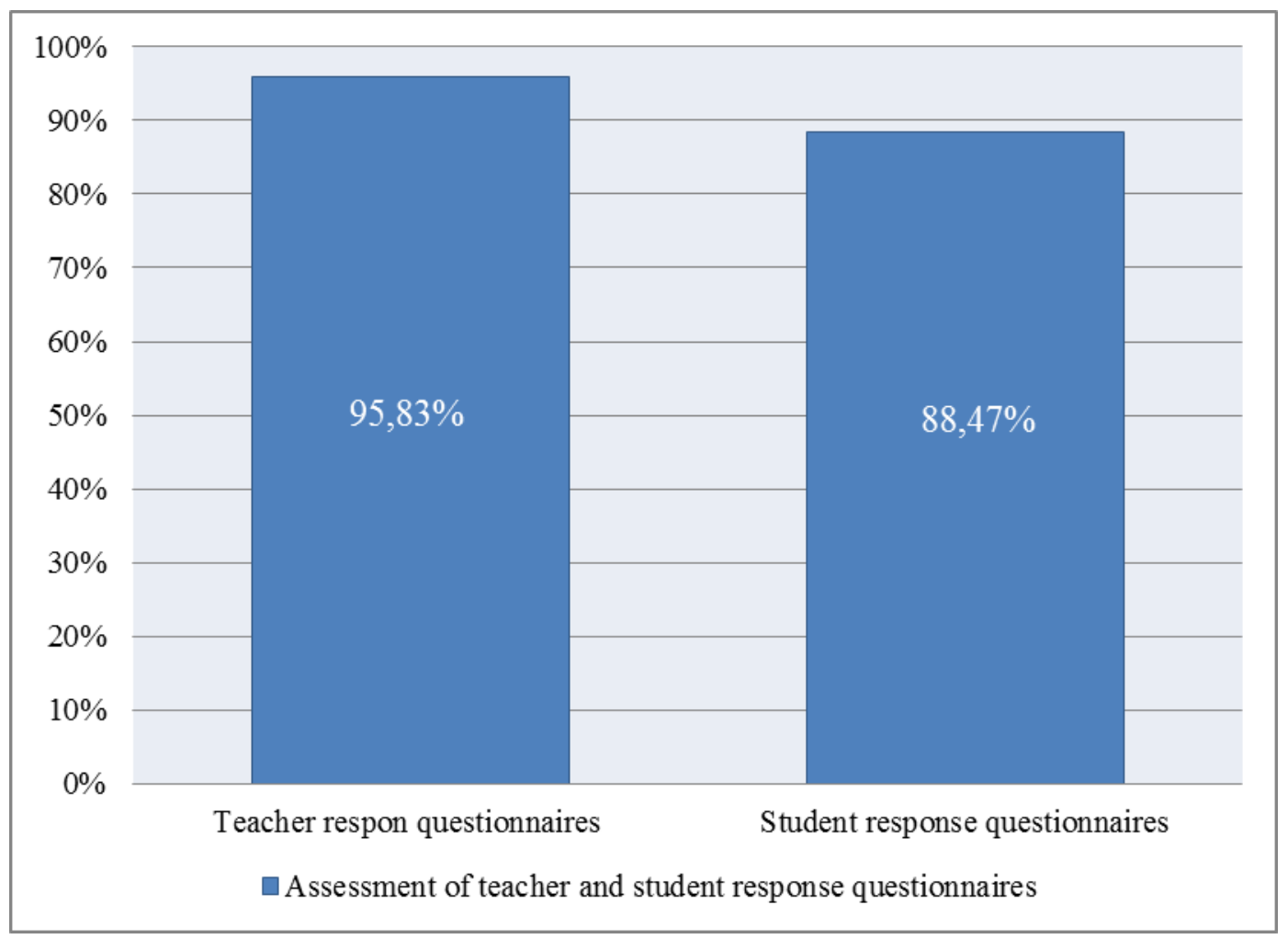

Diagram 2. Assessment of Teacher and Student Response Questionnaires

The diagram above shows that the results of the teacher response questionnaire after testing teaching materials were $95.83 \%$ with very feasible criteria and the results of students' responses to multimodal literacy-based literacy activities with an average percentage of $88.47 \%$ with very feasible criteria.

Teaching materials that are declared feasible by material experts, linguists, and book presentation design experts can then be implemented in learning activities to determine the increase in student literacy activities by using student performance assessment or literacy activity skills after using literacy activity teaching materials.

Table 1. Recapitulation of Literacy Activity Skills Results

\begin{tabular}{|l|l|c|c|c|}
\hline No & $\begin{array}{c}\text { Results of the } \\
\text { Assessment of } \\
\text { Literacy Skills }\end{array}$ & $\begin{array}{c}\text { Average Score } \\
\text { Persentage }\end{array}$ & Category & Criteria \\
\hline $\mathbf{1}$ & Pretest & $60 \%$ & Fair & Medium \\
\hline $\mathbf{2}$ & Posttest & $83 \%$ & Good & High \\
\hline \multicolumn{2}{|r}{ Gain score test } & $57,5 \%$ & Moderate effectiveness \\
\hline
\end{tabular}

Based on the table above, it shows that the results of the posttest assessment after using literacy activity teaching materials are in the high category, which is equal to the results of 
the pretest assessment before using literacy activity teaching materials in "Theme 8, Daerah Tempat Tinggalku, Subtema 2 Keunikan Daerah Tempat Tinggalku" is in the sufficient category. Assessment of literacy activity skills to determine the increase in student literacy activities before using literacy activity teaching materials obtained a score of $60 \%$ in the moderate category and moderate criteria. Posttest has increased by $83 \%$ with good category and high criteria. The effectiveness of literacy activity teaching materials based on multimodal literacy can be seen from the gain score test with a value of $57.5 \%$ and the moderate effectiveness category so that it can be concluded that literacy activity teaching materials have been said to be increased and effective.

\section{Conclusion}

The process of developing literacy activity teaching materials based on multimodal of literacy in "Theme 8, Daerah Tempat Tinggalku, Subtema 2 Keunikan Daerah Tempat Tinggalku" for the grade $4^{\text {th }}$ at SDS Amir Hamzah is done in 5 stages, namely: Analysis, Design, Development, Implementation, and Evaluation. The feasibility assessment by material experts obtained an average score of $85.94 \%$ with very feasible criteria. The feasibility assessment by linguists obtained an average score of $76.9 \%$ with appropriate criteria.The feasibility assessment by design experts obtained an average score of $85.63 \%$ with very feasible criteria. From the three expert validations, an average score of $83 \%$ was obtained with very feasible criteria. The feasibility of teaching materials was also obtained from the results of the teacher's response questionnaire after testing the teaching materials of $95.83 \%$ with very feasible criteria and the results of student responses to multimodal literacybased literacy activities with an average percentage of $88.47 \%$ with criteria very worthy. Based on the results of the validation of the experts, the teacher and student response questionnaires can be concluded that the multimodal literacy-based literacy activity teaching materials developed are suitable for use. Assessment of literacy activity skills to determine the increase in student literacy activities before using literacy activity teaching materials obtained a score of $60 \%$ in the moderate category and moderate criteria. Posttest has increased by $83 \%$ with good category and high criteria. The effectiveness of literacy activity teaching materials based on multimodal literacy can be seen from the gain score value of $57.5 \%$ with the moderate effectiveness category so that it can be concluded that literacy activity teaching materials have been said to be increased and effective.

\section{References}

Abidin, Yunus. 2014. Desain Sistem Pembelajaran Dalam Konteks Kurikulum 2013. Bandung: Refika Aditama.

Benjamin, Amy \& Michael Hugelmayer. 2013. Big skills for The Common Core Literacy Strategies For The 6-12 Classroom. New York London. Routledge Taylor \& Francis Group.

Bezemer, J., \& Kress, G. 2008. Writing in Multimodal Texts A Social Semiotic Account of Designs for Learning. Written Communication. Vol. 25(2), 166-195.

Dewabrata, Mikael. 2019. Hasil PISA 2018 Resmi Diumumkan, Indonesia Alami Penurunan Skor di Setiap Bidang. https://www.zenius.net.

Dewi, Agustina Kusuma. 2019. Pengembangan Kompetensi Multiliterasi Desain Berbasis pada Penerapan Tradisi Komunikasi di Era Indonesia 4.0. Jurnal Desain Indonesia, Vol. 01 (01): 1-6. 
Kern, R. 2000. Literacy and Language Teaching. Oxford: Oxford University Press.

Kress, G. R., \& Van Leeuwen, T. 2006. Reading Images: The Grammar of Visual Design (2nd ed.). New York: Psychology Press.

Kress, G., \& Van Leeuwen, T. 2001. Multimodal Discourse. New York: Bloomsbury Academic.

Kucer, Stephen B. 2014. Dimensions of Literacy. New York: Routledge.

Laksono, Kisyani., et. al. 2018. Strategi Literasi dalam Pembelajaran di Sekolah Menengah Pertama. Jakarta: Kementerian Pendidikan dan Kebudayaan.

Lubis, I. G., Adisaputera, A. Dewi, R. 2020. Development of Teaching Materials Based on People's Stories Assisted In the Graphics of 5 th Grade Students Primary School Muhammadiyah 01 Kota Binjai. Budapest International Research and Critics in Linguistics and Education (BirLE) Journal (3): 1083-1093.

Majid, A. 2013. Perencanaan Pembelajaran Mengembangkan Kompetensi Guru. Bandung: PT Remaja Rosdakarya.

Mastrianto, A., Sariyatun, Suryani, N. 2020. Development of History-Based Digital Book Based on the 19th Century Lampung's People Army Struggle in Local History Lessons. Budapest International Research and Critics in Linguistics and Education (BirLE) (3): 809-819.

Prastowo, A. 2015. Panduan Kreatif Membuat Bahan Ajar Inovatif. Yogyakarta: Diva Press.

Rangkuti, N. J., Ansarif, K., Hadi, W. 2020. The Development of Fantasy Teaching Materials by Using VAK (Visual Auditory Kinesthetic) on 7th Grade Students in SMP Negeri 1 Medan. Budapest International Research and Critics in Linguistics and Education (BirLE) Journal (3): 1170-1181.

Reardon, Sean F., Rachel A. Valentino, dan Kenneth A. Shores. 2012. "Patterns of Literacy among U.S. Students." www.futureofchildren.org.

Sani, R. A., dkk. 2018. Penelitian Pendidikan. Tangerang. Tira Smart.

Sari, Esti Swatika., et. al., 2013. Model Multiliterasi dalam Perkuliahan Pendidikan Bahasa dan Sastra Indonesia. Jurnal Litera. Vol. 12 (2). 246-255.

Siregar, M., Dewi, N. R., Lubis, S. 2020. The Development of Learning Material for Seminar on English Language Teaching Course Based on Flipped Learning. Budapest International Research and Critics in Linguistics and Education (BirLE) Journal (3): 399-347.

Thompson, M. 2008. Multimodal Teaching and Learning: Creating Spaces for Content Teachers. Journal of Adolescent \& Adult Literacy. Vol. 52 (2), 144-153.

Walsh, M. 2011. Multimodal Literacy: Researching Classroom Practice. New South Wales: Primary English Teaching Association (e-lit).

Wiedarti, Pangesti., et. al., (ed.). 2018. Desain Induk Gerakan Literasi Sekolah. Jakarta: Direktorat Jenderal Pendidikan Dasar dan Menengah Kementerian Pendidikan dan Kebudayaan.

World Economic Forum. 2016. "What are the 21st-century skills every student needs?". Dalam https://www.weforum.org/agenda/2016/03/21 st-century-skills-future-jobsstudents/.

Nazila, D. K., Adisaputera, A., and Saragih, A. 2020. Development of Teaching Material for Short Story Writing Experience Based on 7th Grade Students of Junior High School 2 Kejuruan Muda. Budapest International Research and Critics in Linguistics and Education (BirLE) Journal (3): 1137-1150. 